\title{
Pecan Tree Biomass Estimates
}

\author{
Michael W. Smith ${ }^{1,2}$ \\ Department of Horticulture \& Landscape Architecture, Oklahoma State \\ University, Stillwater, OK 74078
}

\author{
Bruce W. Wood \\ US Department of Agriculture, Agricultural Research Service, Southeastern \\ Fruit and Tree Nut Research Laboratory, Byron, GA 31008
}

Additional index words. Carya illinoinensis, weight, allometry, allometric model, temperate tree

\begin{abstract}
Allometric equations were developed for orchard-grown pecan [Carya illinoinensis (Wangenh.) C. Koch] trees. Trees, ranging in size from 22 to $33 \mathrm{~cm}$ in trunk diameter $1.4 \mathrm{~m}$ above the ground, were destructively harvested from two sites. The entire aboveground portion of each tree was harvested and then divided into leaves, current season's shoots, and branches $\geq 1$ year old plus trunk. Roots were sampled by digging a trench beginning beneath the trunk and extending to one-half the distance to an adjacent tree, then separating the roots from the soil. Roots were then divided into those less than $1 \mathrm{~cm}$ in diameter and those $\geq 1 \mathrm{~cm}$ in diameter. Equations in the form $Y=e^{a} X^{b}$ were developed to estimate dry biomass of most tree components and the whole tree, where $Y$ is the dry weight, $e$ is the base of the natural logarithm, $X$ is the trunk diameter at $1.4 \mathrm{~m}$ above the ground, and $a$ and $b$ are coefficients. A linear equation provided the best fit for estimating the weight of the current season's growth. Power equations were also developed to estimate the weights of inner bark and wood for different size trunks or branches.
\end{abstract}

Methods to estimate biomass of either individual trees or tree populations are useful for foresters, ecologists, and scientists. Biomass estimates of tree populations are valuable for such studies as ecosystem productivity, energy and nutrient flows, fire behavior, carbon utilization and sequestering, plus many other applications. Most models for biomass estimation have been developed and used by the forestry or ecology community. These models normally divide aboveground components into bole or main stem, bole bark, and crown (Parresol, 1999). Occasionally a fourth component, below-ground biomass, is estimated.

Biomass equations for southern US hardwood and softwood species have been compiled by Clark (1987). More recently, a review of biomass estimators for tree species in the United States has been published (Jenkins et al., 2003), followed by a comprehensive database of biomass regressions for North America tree species (Jenkins et al., 2004). However, no equations have been developed to estimate pecan biomass. Jenkins and colleagues (2004) developed generic equations to estimate above-ground biomass of selected hardwood and softwood groups. They also developed equations to estimate the component ratios of hardwood and softwood species.

Received for publication 21 Mar. 2006. Accepted for publication 18 Apr. 2006. Approved for publication by the Oklahoma Agricultural Experiment Station.

${ }^{1}$ Regents Professor.

${ }^{2}$ To whom reprint requests should be addressed; e-mailmike.smith@okstate.edu production accounted for another $27 \%$ to $34 \%$ of the $\mathrm{N}$ utilization, and the other tree components used $9 \%$ to $21 \%$.

A study using loblolly pine (Pinus taeda L.) reported that biomass was partitioned as $17 \%$ crown, $63 \%$ stem, and $20 \%$ roots (Van Lear and Kapeluck, 1995). Fine roots accounted for $11 \%$ of the root mass, but contained $24 \%$ to $30 \%$ of the nutrients in the root system. Fine roots and foliage made up only $4 \%$ of the stand's biomass, but had one-fourth of the stand's $\mathrm{N}$ and phosphorus (P).

Biomass estimation of individual trees is also useful in horticultural studies, especially those involving mineral nutrition. Three recently published studies on $\mathrm{N}$ nutrition of pecan (Acuña-Maldonado et al., 2003; Kraimer et al., 2001, 2004) used equations developed from destructively harvested forest-grown black oak (Quercus velutina Lam.) trees (King and Schnell, 1972) to estimate pecan tree biomass components. Extrapolation of black oak models to pecan trees provides questionable information and their use entails major limitations and substantial error sources. First, and most obvious, is that such equations were not developed to estimate pecan tree biomass, a species exhibiting a different growth form than black oak. One striking difference is that Carya spp. produce about three times the leaf weight as black oak trees (Schnell, 1978). Acuña-Maldonado and associates (2003) developed equations from destructively harvested pecan trees to estimate leaf weight because of the discrepancy in leaf production between black oak and pecan.

A second limitation is that equations for relatively shaded forest-grown trees do not accurately estimate the biomass components of relatively nonshaded urban-grown (Nowak, 1994) or open-grown trees. Typically in a commercial pecan orchard, grafted trees are initially trained to a modified leader and are subsequently managed with little or no pruning. These trees obviously exhibit morphological traits considerably different from those of forest-grown, shaded black oaks. The predictive ability of equations to estimate biomass of orchard trees is therefore likely to be most accurate if derived from orchard-grown trees. Another potential limitation of extrapolating existing equations
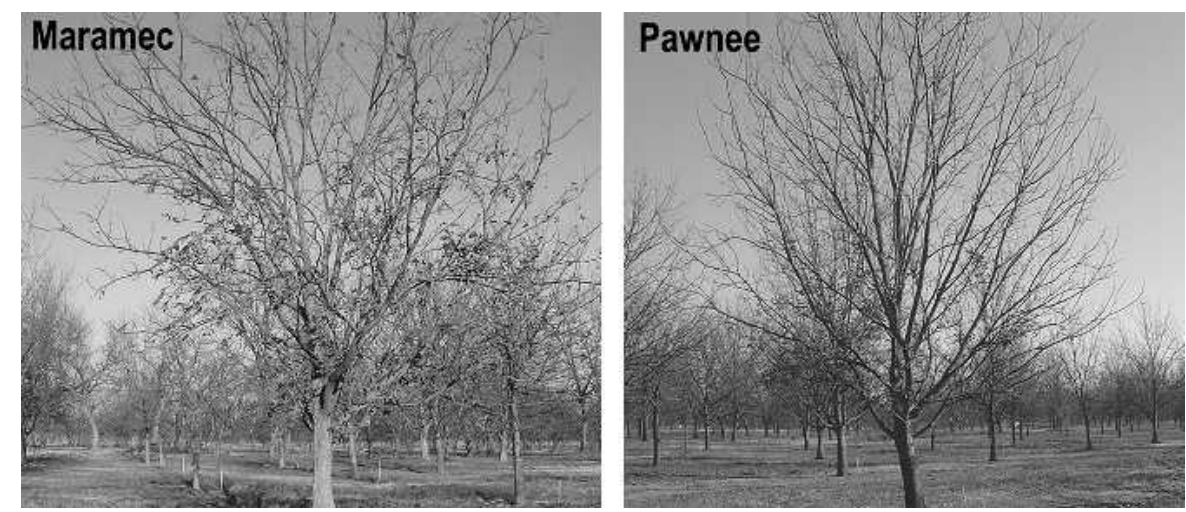

Fig. 1. Typical growth forms of 'Maramec' and 'Pawnee' trees. 


\begin{tabular}{|c|c|c|c|c|c|c|c|c|}
\hline \multirow[b]{4}{*}{ Tree component } & \multicolumn{8}{|c|}{ Dry weight of tree component, $\mathrm{kg}$} \\
\hline & \multicolumn{5}{|c|}{ Madill site } & \multicolumn{3}{|c|}{ Sparks site } \\
\hline & \multicolumn{8}{|c|}{ Trunk diameter, $\mathrm{cm}$} \\
\hline & 21.9 & 23.1 & 23.5 & 24.8 & 25.8 & 28.0 & 32.0 & 33.0 \\
\hline Roots $<1$-cm diameter & 24.1 & 20.9 & 34.2 & 23.2 & 37.7 & 68.7 & 81.0 & 64.2 \\
\hline Roots $\geq 1-\mathrm{cm}$ diameter & 58.6 & 42.4 & 76.5 & 63.1 & 188.6 & 170.6 & 192.9 & 180.2 \\
\hline Bark + wood $>3$ years old & 181.3 & 177.5 & 198.3 & 269.5 & 300.1 & 459.7 & 684.1 & 924.8 \\
\hline Current season shoots & 5.7 & 6.6 & 3.7 & 6.8 & 6.7 & 5.9 & 8.1 & 8.7 \\
\hline Leaves & 29.7 & 33.5 & 23.7 & 36.0 & 38.3 & 46.3 & 75.8 & 79.5 \\
\hline
\end{tabular}

derived from forest-grown trees to horticultural applications is their inclusion of outer bark. Forestry estimates typically include the dead outer bark, because it is of potential use. However, for nutritional physiology purposes, the outer bark is usually unimportant, whereas the inner bark serves as a storage site, especially for nitrogenous reserves (Coleman et al., 1992; Wetzel et al., 1989). Another limitation is that estimated tree weights can differ substantially for the same hardwood species among geographic regions (Clark, 1982).

Accurate equations are essential for studies such as nutrient absorption efficiency and partitioning, carbon allocation, and other applications. Our objective was to develop allometric equations for orchard-grown pecan trees to estimate the biomass of the whole tree and selected components.

Table 2. Equations for estimating the dry weight, in kilograms, of selected pecan tree parts.

\begin{tabular}{lcc}
\hline Plant part & \multicolumn{1}{c}{ Equations } & $R^{2}$ \\
\hline All roots & $\mathrm{Y}=\mathrm{e}^{-5.9498} \mathrm{X}^{3.3413}$ & $0.73^{* *}$ \\
Roots $<1 \mathrm{~cm}$ in diameter & $\mathrm{Y}=\mathrm{e}^{-6.6398} \mathrm{X}^{3.1537}$ & $0.79^{* *}$ \\
Roots $\geq 1 \mathrm{~cm}$ in diameter & $\mathrm{Y}=\mathrm{e}^{-6.5543} \mathrm{X}^{3.4266}$ & $0.68^{* *}$ \\
Current season shoots & $\mathrm{Y}=-0.9+0.2814 \mathrm{X}$ & $0.57^{*}$ \\
Leaves & $\mathrm{Y}=\mathrm{e}^{-5.103} \mathrm{X}^{2.703}$ & $0.91^{* * *}$ \\
Above-ground perennial parts, excluding current & $\mathrm{Y}=\mathrm{e}^{-7.589} \mathrm{X}^{4.1003}$ & $0.98^{* * *}$ \\
$\quad$ & & \\
season shoots & $\mathrm{Y}=\mathrm{e}^{-7.3917} \mathrm{X}^{4.0459}$ & $0.98^{* * *}$ \\
Above-ground perennial parts & $\mathrm{Y}=\mathrm{e}^{-6.4051} \mathrm{X}^{3.8551}$ & $0.96^{* * *}$ \\
Above- and below-ground perennial parts & $\mathrm{Y}=\mathrm{e}^{-6.0032} \mathrm{X}^{3.7578}$ & $0.97^{* * *}$ \\
\hline${ }^{*, * * * * * *}$ Significant at $5 \%, 1 \%$, or $0.1 \%$ respectively. & \\
${ }^{2} \mathrm{Y}=$ dry weight in kilograms; $=2.71828 ; \mathrm{X}=$ trunk diameter in centimeters. &
\end{tabular}

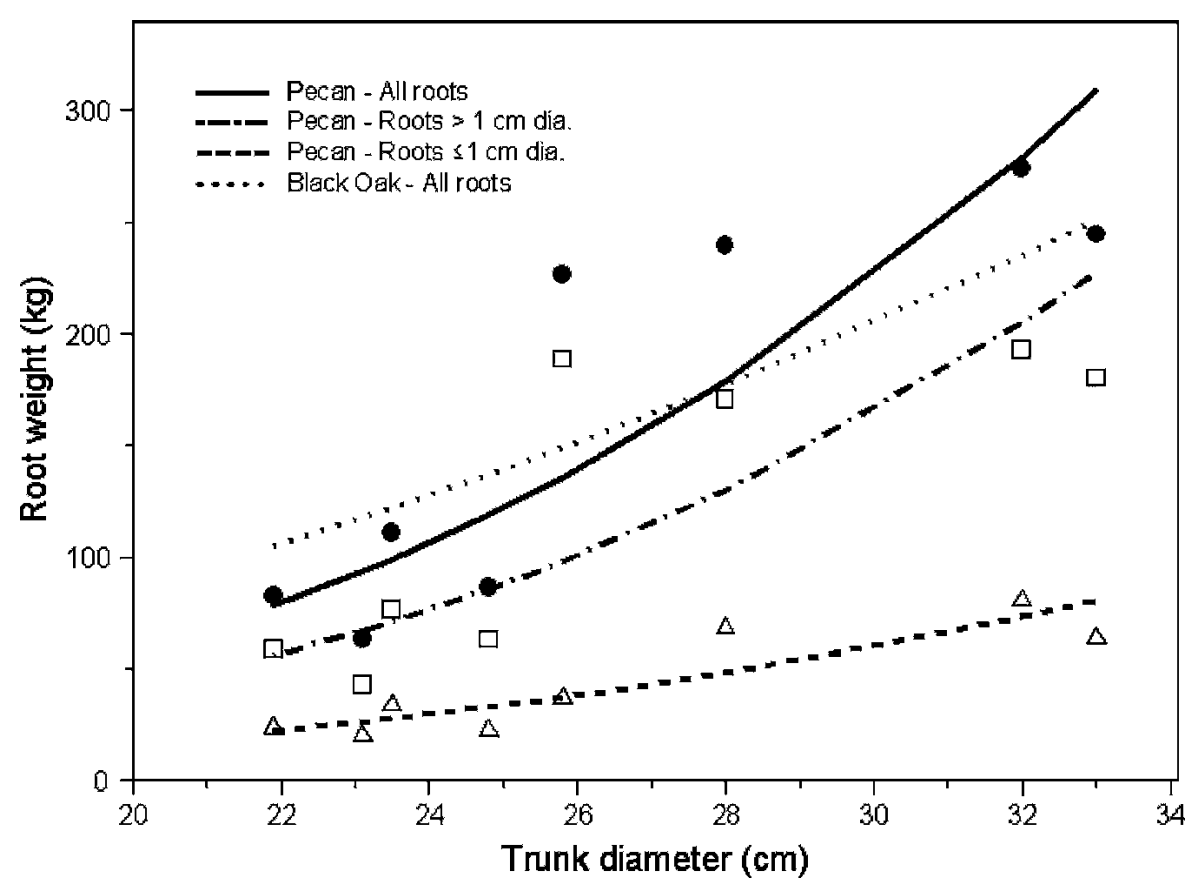

Fig. 2. Estimations of pecan root biomass for trees with different trunk diameters. Estimates are for all roots, roots $\geq 1 \mathrm{~cm}$ in diameter, and roots less than $1 \mathrm{~cm}$ in diameter using equations developed for pecan (Table 2), and all roots using equations developed for black oak (King and Schnell, 1972). Open triangles are observed weights for roots less than $1 \mathrm{~cm}$ in diameter, open boxes are weights for roots $\geq 1$ $\mathrm{cm}$ in diameter, and closed circles represent weights of all roots.

\section{Materials and Methods}

\section{Sparks Site}

The first site was at the Pecan Research Station in central Oklahoma near Sparks. Fifteen-year-old 'Maramec' trees, spaced $10.7 \times 10.7 \mathrm{~m}$ apart, were growing in a Port silt loam (fine silty, mixed, superactive, thermic Cumulic Haplustolls). Trees were grafted on open-pollinated seedling rootstocks. After 1 year of scion growth, the trees were transplanted to their orchard location. Trees were not irrigated and rainfall averaged $975 \mathrm{~mm}$ annually. Trees were initially trained to a modified leader during years 1 through 6 , and then not pruned other than to remove broken branches or limbs that interfered with harvest. Between-tree spacing was sufficient to ensure that canopies had not encroached enough to influence tree morphology markedly.

\section{Madill Site}

'Pawnee' trees that were $\approx 13$ years old were harvested from Hauani Creek Ranch in south central Oklahoma near Madill. 'Pawnee' scions had been grafted onto native pecan rootstocks growing in a Madill fine sandy loam (coarse loamy, mixed, active, nonacid, thermic Typic Udifluvents). The native sapling density had been reduced to approximate a $10.7 \times 10.7-\mathrm{m}$ spacing before grafting. Trees were not irrigated and rainfall averaged $1053 \mathrm{~mm}$ annually. Initial training and subsequent pruning was similar to that at the Sparks site.

\section{Sample Collection and Management}

Trees at both sites were harvested and handled in a like manner. Three trees were harvested from the Sparks site during 16 to 23 Oct. 1998. Five trees were harvested from the Madill site during 13 to 15 Sept. (tops) and 20, 22, and 27 Sept. (roots) 2004. Trunk diameters were measured $1.4 \mathrm{~m}$ above the soil line before harvest (Table 1). Each tree was cut at the soil line and then the entire tree was divided into leaves, current season's shoots, and branches $\geq 1$ year plus trunk. Roots of each tree at the Sparks site were sampled by excavating two $51-\mathrm{cm}$ wide $x$ 5.3-m long (one-half the distance between trees) trenches $\approx 2 \mathrm{~m}$ deep at a right angle from the crown and centered on the plane of the trunk (Snowdon et al., 2002). The water table was $\approx 2 \mathrm{~m}$ below the soil surface, and no roots were observed below that point. At the Madill site, the excavated area was $81 \mathrm{~cm}$ wide, $5.3 \mathrm{~m}$ long, and $\approx 2.5 \mathrm{~m}$ deep. The water table was encountered at $\approx 2.5 \mathrm{~m}$ deep. 


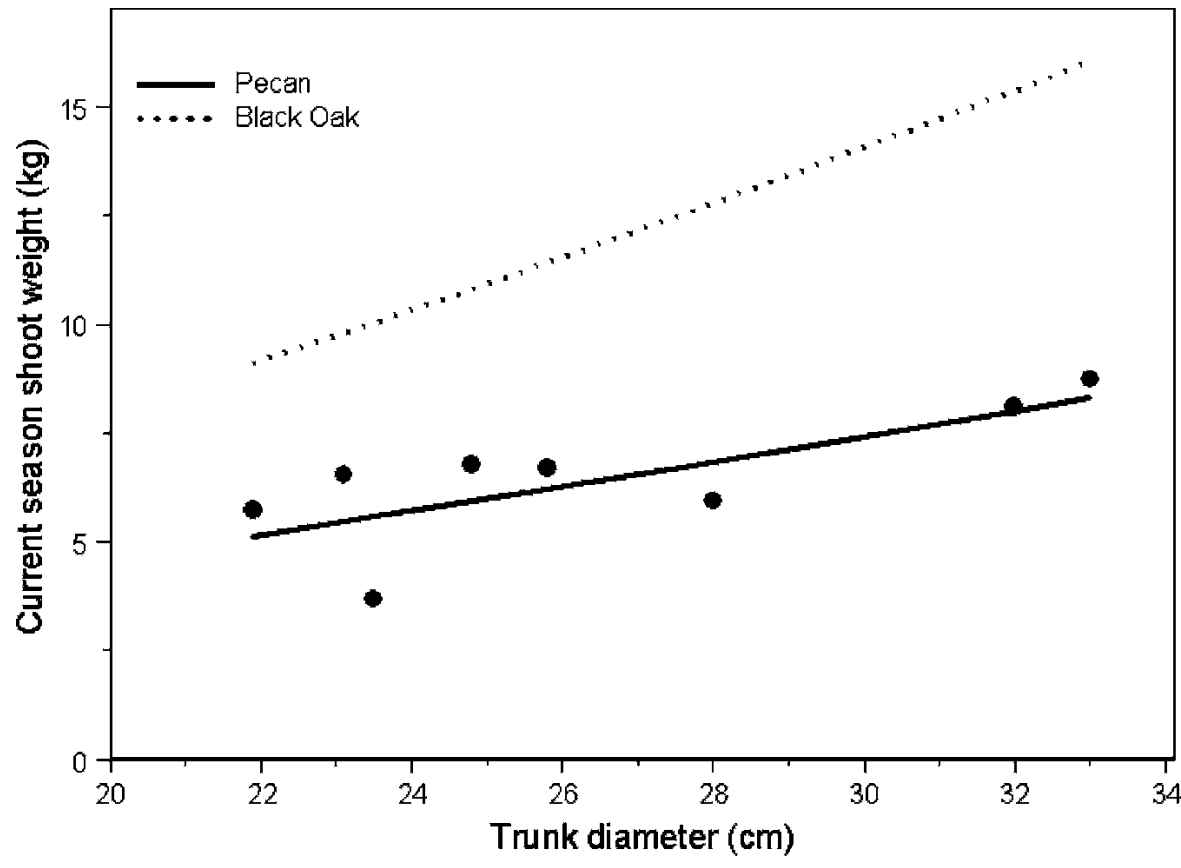

Fig. 3. Estimates of pecan current season shoot biomass using equations developed for pecan (Table 2) and for shoots less than $1.27 \mathrm{~cm}$ in diameter using equations developed for black oak (King and Schnell, 1972). Closed circles are observed weights of current season pecan shoots.

Roots were removed from the excavated soil by hand sieving the entire soil volume. The roots were then divided into two size classes: those $<1 \mathrm{~cm}$ and those $\geq 1 \mathrm{~cm}$ in diameter. Leaves and current season's shoots were dried intact at $70{ }^{\circ} \mathrm{C}$. Branches, roots, and the trunk were cut into sections to fit a walkin dryer, dried to a constant weight, and then weighed. Root weight per tree was calculated based on the fraction of the root area sam-

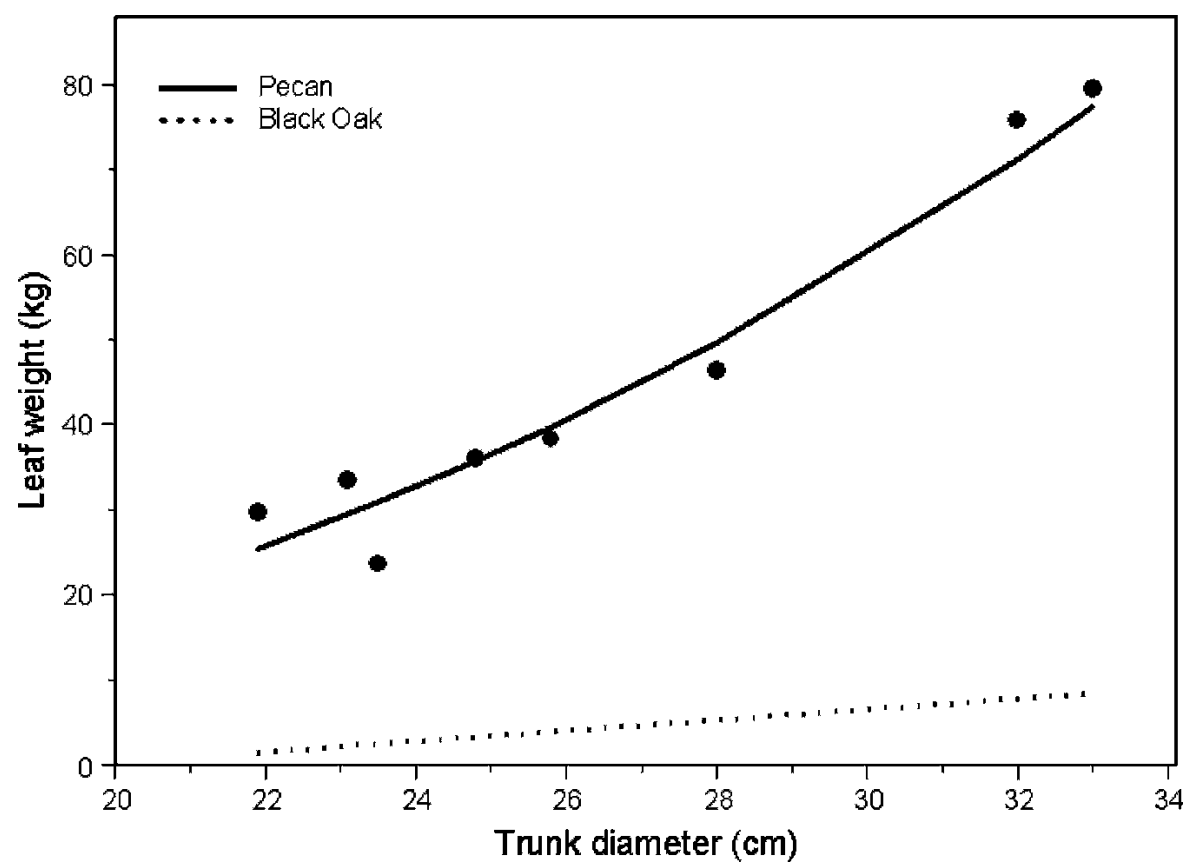

Fig. 4. Estimates of pecan leaf weights using equations developed for pecan (Table 2) and for black oak (King and Schnell, 1972). Closed circles are observed weights of leaves.
Disks ranged in size from 3.1 to $31.7 \mathrm{~cm}$ in diameter. The outer bark was removed and discarded, and then the individual disks were separated into inner bark (phloem) and wood (xylem), dried, and weighed.

\section{Statistical Analysis}

The most commonly used mathematical model for biomass modeling is the power function:

$$
\mathrm{Y}=a \mathrm{X}^{b}
$$

where $\mathrm{Y}$ is the weight, $a$ and $b$ are coefficients, and $\mathrm{X}$ is the trunk diameter at $1.4 \mathrm{~m}$ height above the ground (Zianis and Mencuccini, 2004). The trunk diameter and component weights were transformed using natural logarithms, and then regression equations were fit using least squares techniques to estimate the dry weight of each tree component as well as that of the whole tree (Draper and Smith, 1966). These equations take the form

$$
\operatorname{Ln} \mathrm{Y}=\operatorname{Ln} \mathrm{a}+\mathrm{b} \operatorname{Ln} \mathrm{X}
$$

and can be rewritten as

$$
\mathrm{Y}=\mathrm{e}^{a} \mathrm{X}^{b}
$$

where $\mathrm{Y}$ is the dry weight, e is the natural logarithm base, $a$ and $b$ are coefficients, and $\mathrm{X}$ is the trunk diameter in centimeters. Power function equations were suitable to estimate weights of the whole tree and all components, except current season's shoots. A linear equation, $\mathrm{Y}=\mathrm{a}+\mathrm{bX}$, proved suitable for estimating the weight of current season's shoots.

Power function equations were fit using techniques described earlier to predict weight of bark or wood for various-diameter trunks or branches. In addition, the percentage of inner bark and wood from the disks was calculated for various ages and diameters.

\section{Results and Discussion}

'Maramec' tends to have wider crotch angles than 'Pawnee', resulting in a more spreading growth habit (Fig. 1). Branching pattern between the two cultivars was similar. Although differences in growth habit were visible, they were unlikely to have a large effect on component weights. Tree crowding as the trees fill their allotted space is more likely to affect component weight than small differences in growth habit. These trees were harvested before they crowded.

Trees harvested at the Sparks site ranged in trunk diameter from 28 to $33 \mathrm{~cm}$ at breast height (Table 1). At the Madill site trees were 21.9 to $25.8 \mathrm{~cm}$ in diameter. Equations estimating component or whole tree weights accounted for $57 \%$ to $98 \%$ of the variation among trees and were significant at the 5\% level or greater (Table 2).

Figures include estimated weights using equations for pecan that were developed in this study and those for black oak (King and Schnell, 1972), because they have been used 


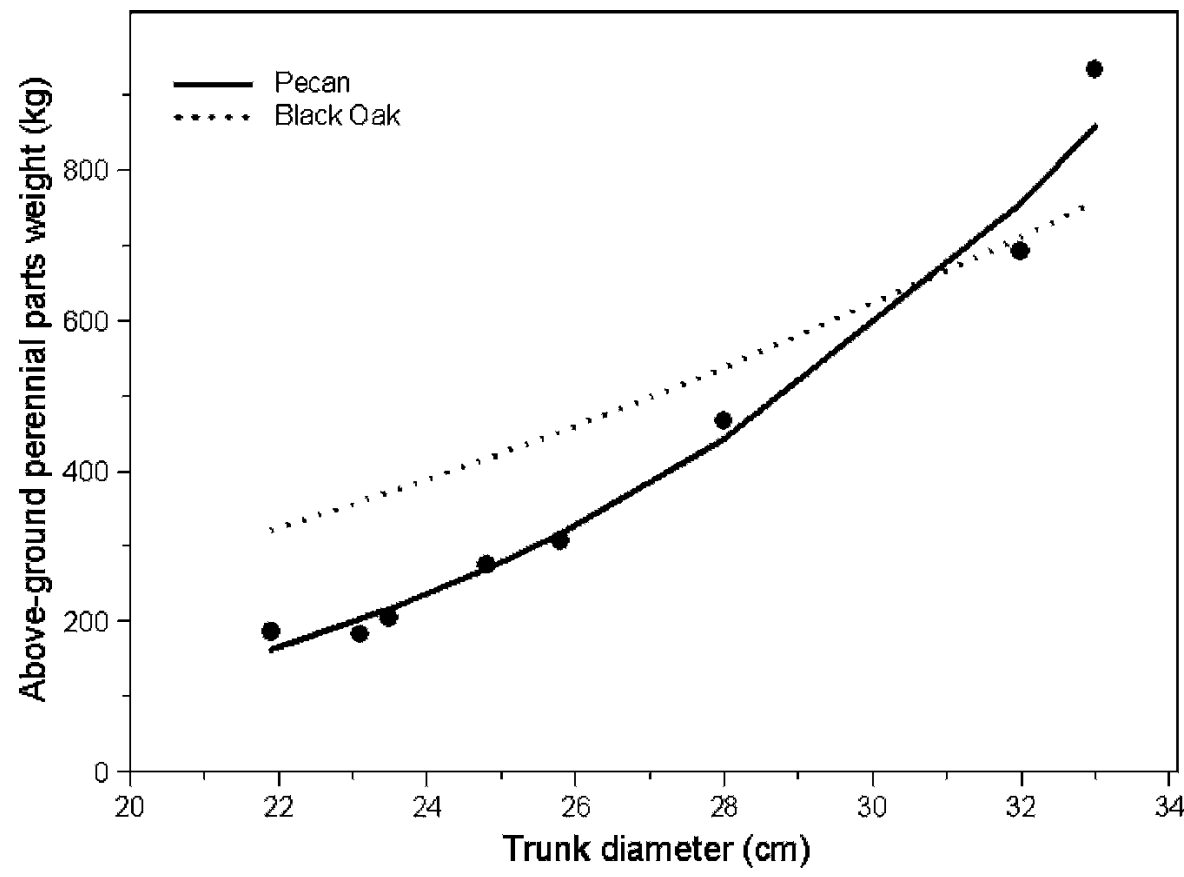

Fig. 5. Estimates of pecan tree above-ground perennial parts using equations developed for pecan (Table 2) and for black oak (King and Schnell, 1972). Closed circles are observed weights.

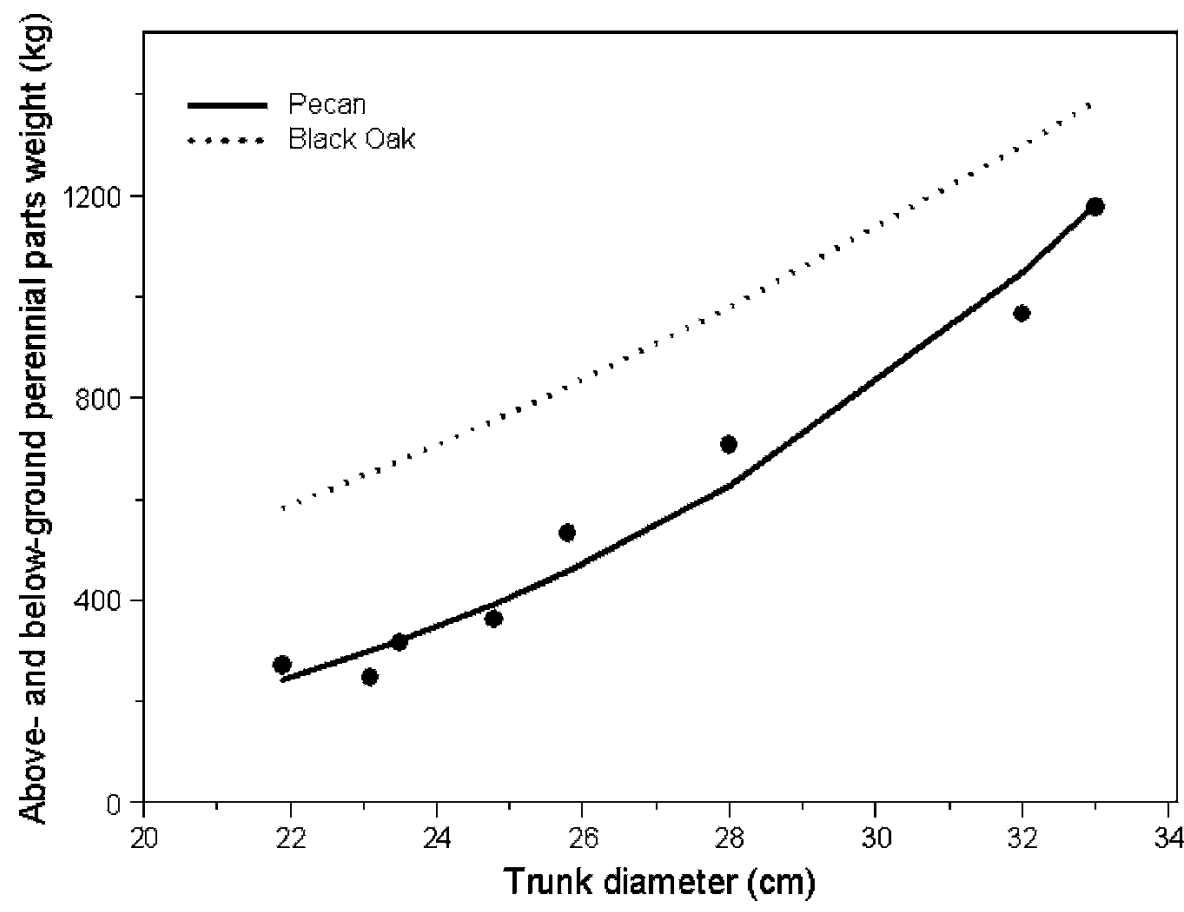

Fig. 6. Estimates of pecan tree above- and below-ground perennial parts using equations developed for pecan (Table 2) and for black oak (King and Schnell, 1972). Closed circles are observed weights.

to estimate pecan tree weights (Acuña-Maldonado et al., 2003; Kraimer et al., 2001, 2004). Total root weight using the black oak equation overestimated weight for small trees and underestimated root weight of larger trees compared with the pecan equation (Fig. 2). The root weight equation for black oak was derived from trunk diameters of the black oaks and the assumption that $25 \%$ of the tree's total fresh weight was stump and roots (King and Schnell, 1972). Typically, $22-\mathrm{cm}$ diameter trees and $26 \%$ for $33-\mathrm{cm}$ diameter trees. Root weights as a percent of the complete tree dry weight were estimated to be $15 \%$ for black oak (King and Schnell, 1972), 24\% for mixed Carya spp. (Schnell, 1978 ), and $16 \%$ for the hardwood group containing hickory (Jenkins et al., 2004) for trees in the 22 to $33-\mathrm{cm}$-diameter size class compared with an average of $23 \%$ for pecan. This is similar to the $24 \%$ estimated for Carya spp. (Schnell, 1978), especially considering the Carya spp. were forest grown and the pecans were orchard grown.

Current season shoot weights were substantially overestimated by the black oak equation compared with the equation derived from direct pecan measurements (Fig. 3). Overestimates ranged from $59 \%$ for $22-\mathrm{cm}$ diameter trees to $83 \%$ for $33-\mathrm{cm}$-diameter trees. It should be pointed out that the black oak equation did not directly estimate the weight of current season shoots, but estimated the weight of shoots less than $1.27 \mathrm{~cm}$ in diameter. Most current season shoots of pecan would fall within the size range used for black oak, but some vigorous shoots, particularly in the upper canopy, exceed this diameter. Therefore, the overestimate using the black oak equation was even greater than stated here. It is surprising that the less than $1.27-\mathrm{cm}$-diameter size class for black oak overestimated current season pecan shoots. In a forest situation, much of the lower canopy is lost compared with orchard-grown trees. It therefore seems logical that orchard-grown trees would have many more current season shoots than forest-grown black oak trees. It appears that the equation for shoots less than $1.27 \mathrm{~cm}$ in diameter includes many 1- and 2-year-old shoots of black oak in addition to current season shoots to accumulate up to $83 \%$ more weight for the same tree size.

Leaf weights were substantially underestimated using black oak equations compared with those derived from direct measurements of pecan (Fig. 4). King and Schnell (1972) obtained leaf data for 8 of the 26 trees in their study. They indicated that data for six of the eight were suspect because they were harvested in the fall after trees began to defoliate or in the spring before the leaves had fully expanded. The black oak equation underestimated $22-\mathrm{cm}$-diameter pecans 21-fold and 33-cm-diameter trees by 9.5 times. To avoid this problem Acuna-Maldonado and associates (2003) developed an equation to estimate leaf weight from three destructively harvested pecan trees. Their leaf weight estimates were $32 \%$ lighter for 22-cm-diameter trees and 2\% heavier for 33-cm-diameter trees compared with the pecan equation developed in this study.

The equation estimating of the aboveground perennial parts accounted for $98 \%$ of the data variation (Fig. 5, Table 2). Mass estimates using the black oak equation overestimated the weight by $71 \%$ for $22-\mathrm{cm}$ diameter trees and underestimated weight by $19 \%$ for $33-\mathrm{cm}$-diameter trees. The equation to estimate above- and below-ground 


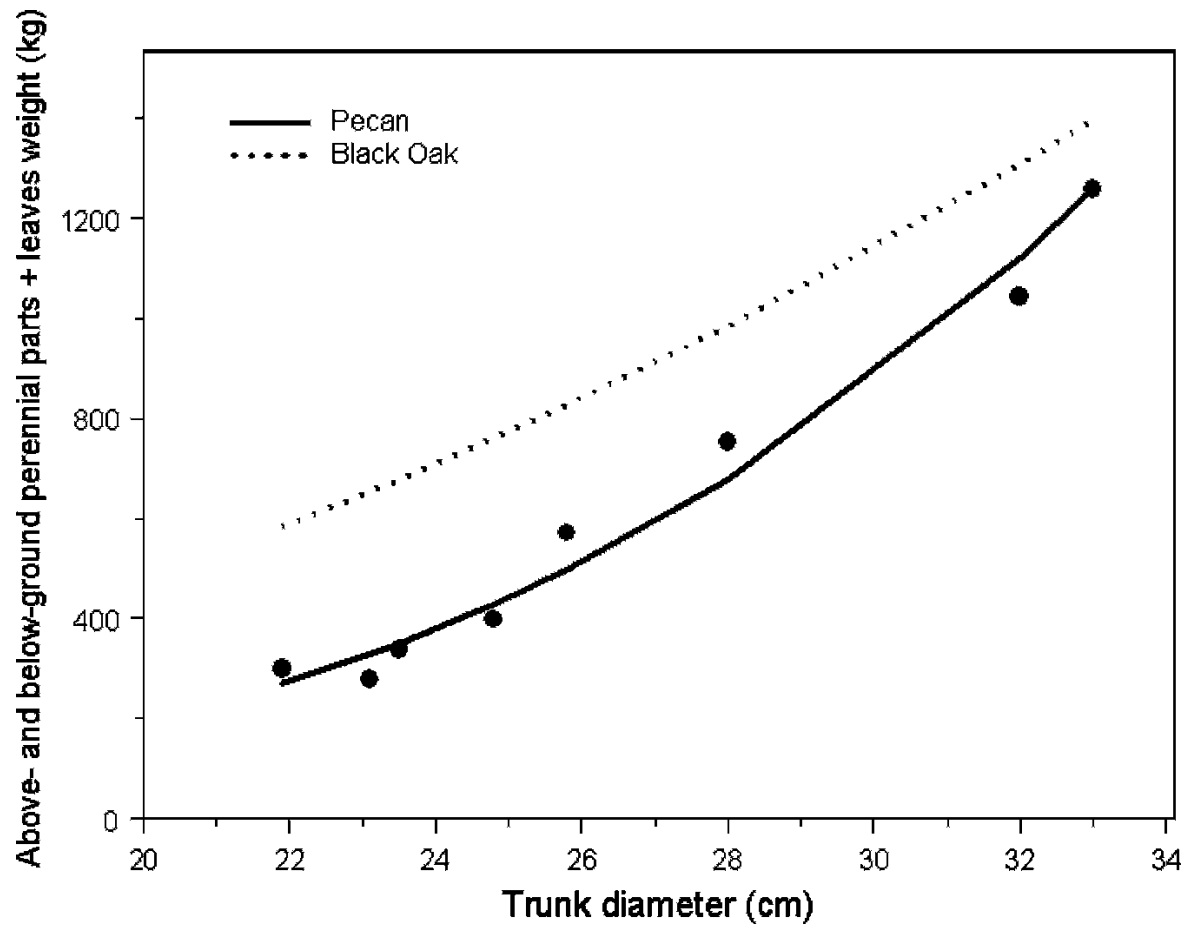

Fig. 7. Estimates of pecan tree above- and below-ground perennial parts plus leaves using equations developed for pecan (Table 2) and for black oak (King and Schnell, 1972). Closed circles are observed weights.

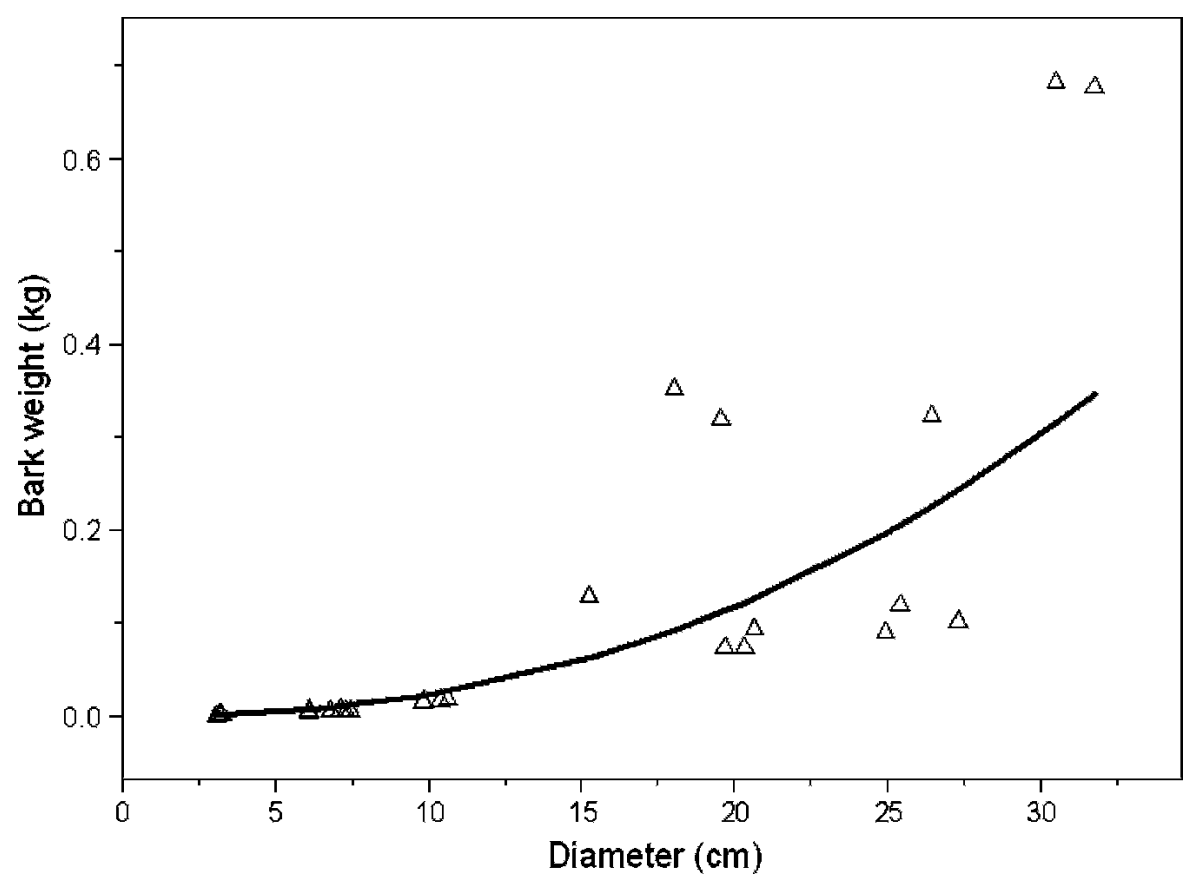

Fig. 8. The relationship between trunk or branch diameter and inner bark weight is $\mathrm{Y}=\mathrm{e}^{-9.1711} \mathrm{X}^{2.3457}$, where $\mathrm{Y}$ is the bark weight in kilograms, e is 2.71828 , and $\mathrm{X}$ is the trunk or branch diameter in centimeters. $R^{2}=0.88$, F-test $<0.001$.

perennial parts accounted for $96 \%$ of the variation (Fig. 6, Table 2). Black oak equations overestimated weights by $115 \%$ for $22-\mathrm{cm}$-diameter trees and $18 \%$ for $33-\mathrm{cm}$ diameter trees compared with the equation developed for pecan. When the leaves were combined with the above- and below-ground perennial parts, an equation accounting for
Table 3. The percentage of inner bark and wood from wood disks of varying sizes collected from pecan trees at two sites.

\begin{tabular}{lcc}
\hline & \multicolumn{2}{c}{ Dry weight $\pm \mathrm{sd}, \%$} \\
\cline { 2 - 3 } Tissue age, diameter & Inner bark & Wood \\
\hline 1 and $2 \mathrm{y}, 3.1-3.3 \mathrm{~cm}$ & $14.7 \pm 0.9$ & $85.3 \pm 0.9$ \\
$3 \mathrm{y}, 6.1-7.5 \mathrm{~cm}$ & $11.3 \pm 1.2$ & $88.7 \pm 1.2$ \\
$>3 \mathrm{y}, 9.8-32 \mathrm{~cm}$ & $11.0 \pm 2.1$ & $89.0 \pm 2.1$ \\
\hline
\end{tabular}

fraction of tree component mass as age increased. Equations estimating bark weight for various diameters account for $88 \%$ of the variation and were highly significant. Inspection of the graph suggests that weight predictions are very accurate for small diameters, but may underestimate weights for large diameters (Fig. 8). Estimates for wood appear to have the same bias as that for bark (Fig. 9).

In summary, allometric equations are presented for pecan trees typical to those found in relatively young commercial orchards. These equations are the most accurate to date for estimating the previously described biomass components. The range of tree size covered, 22 to $33 \mathrm{~cm}$ in diameter, is typical of diameters exhibited by orchard trees when they first begin severe alternate bearing; thus, the equations are potentially useful in efforts to estimate organic and inorganic resources in trees and their organs. These data provide a foundation on which future studies can build in efforts to produce allometric equations that accurately describe biomass components of pecan trees over a wide range of trunk diameters encountered in orchard situations.

\section{Literature Cited}

Acuña-Maldonado, L.E., M.W. Smith, N.O Maness, B.S. Cheary, B.L. Carroll, and G.V. Johnson. 2003. Influence of nitrogen application time on nitrogen absorption, partitioning, and yield of pecan. J. Amer. Soc. Hort. Sci. 128:155-162.

Catchpole, W.R. and C.J. Wheeler. 1992. Estimating plant biomass: A review of techniques. Aust. J. Ecol. 17:121-131.

Clark, A., III. 1982. Predicting biomass production in the south. Proc. Ann. For. Symp.: Predicting Growth and Yield in the Mid-south. 31:119-139.

Clark, A., III. 1987. Summary of biomass equations available for softwood and hardwood species in the southern United States estimating tree biomass regressions and their error. US Dept. Agri. Proc. Forest Inventory Estimates Workshop. Syracuse, N.Y.

Coleman, G.D., T.H. Chen, and L.H. Fuchigami. 1992. Complementary DNA cloning of poplar bark storage proteins and control of its expression by photoperiod. Plant Physiol. 98:687-693.

Draper, N.R. and H. Smith. 1966. Applied regression analysis. Wiley, New York.

Fogel, R. 1983. Root turnover and productivity of coniferous forest. Plant Soil 71:75-85.

Helmisaari, H., K. Makkonen, S. Kellomäki, E. Valtonen, and E. Mälkönen. 2002. Below- and above-ground biomass, production and nitrogen use in Scots pine stands in eastern Finland. For. Ecol. Manage. 165:317-326.

Jenkins, J.C., D.C. Chojnacky, L.S. Heath, and R.A. Birdsey. 2003. National-scale biomass 


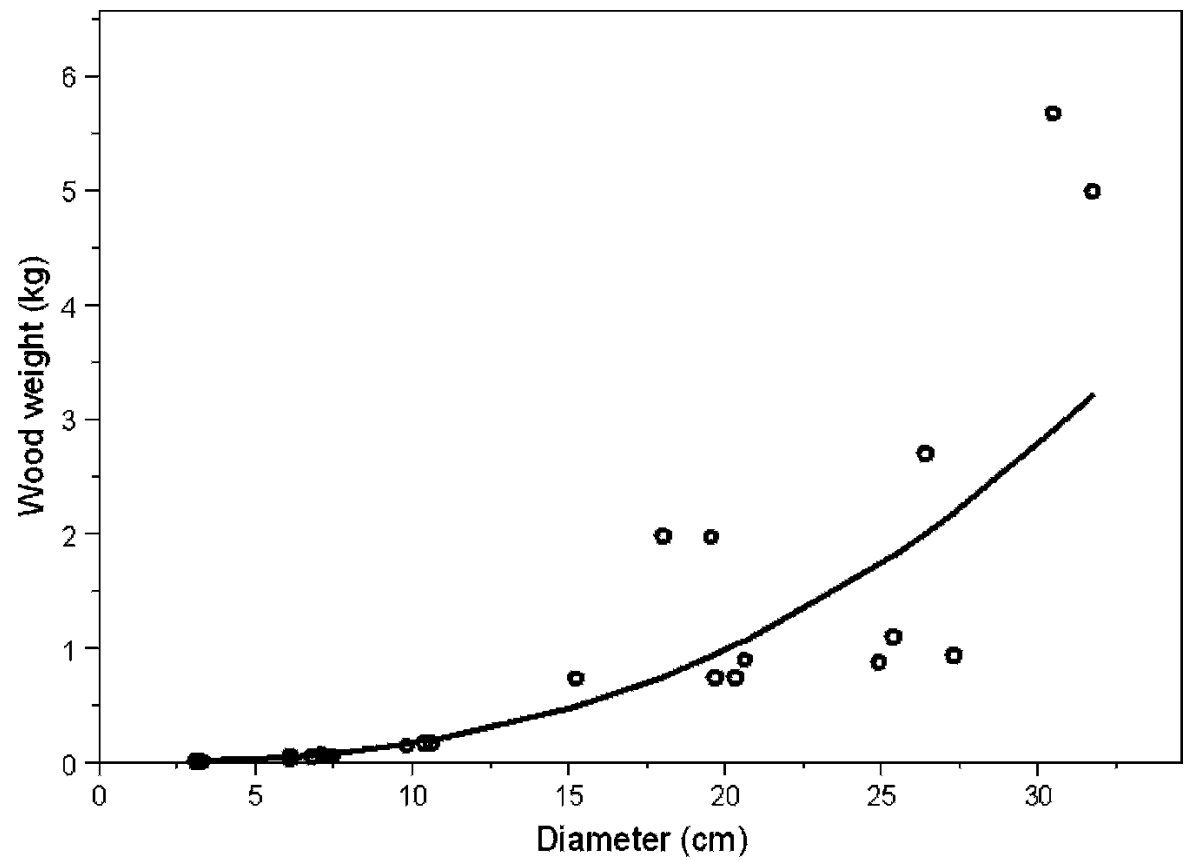

Fig. 9. The relationship between trunk or branch diameter and wood weight is $\mathrm{Y}=\mathrm{e}^{-7.9886} \mathrm{X}^{2.5609}$, where $\mathrm{Y}$ is wood weight in kilograms, e is 2.71828 , and $\mathrm{X}$ is the trunk or branch diameter in centimeters. $R^{2}=0.95$, F-test $<0.0001$.

estimators for United States tree species. For. Sci. 49:12-35

Jenkins, J.C., D.C. Chojnacky, L.S. Heath, and R.A Birdsey. 2004. Comprehensive database of diameter-based biomass regressions for North American tree species. U.S. Dept. of Agri. For. Serv. General technical report NE-319. Newtown Square, $\mathrm{Pa}$.
Kraimer, R.A., W.C. Lindemann, and E.A. Herrera. 2004. Recovery of late-season $15 \mathrm{~N}$ labeled fertilizer applied to pecan. HortScience 39:256-260.

Nowak, D.J. 1994. Urban forest structure: The state of Chicago's urban forest, p. 83-94. In: E.G. McPherson, D.J. Nowak, R.A. Roundtree (eds.). Chicago's urban forest ecosystem: Results of the Chicago Urban Forest Climate Project. General technical report NE-186. USDA For. Serv. Northeast. For. Exp. Sta., Radnor, Penn.

Parresol, B.R. 1999. Assessing tree and stand biomass: A review with examples and critical comparisons. For. Sci. 45:573-593.

Parresol, B.R. 2001. Additivity of nonlinear biomass equations. Can. J. For. Res. 31:865-878.

Santantonio, D., R.K. Hermann, and W.S. Overton. 1977. Root biomass studies in forest ecosystems. Pedobiologia (Jena) 17:1-31.

Schnell, R.L. 1978. Biomass of hickory tree components. Technical note B-30. Division of Forestry, Fisheries and Wildlife Development. Tenn. Valley Authority, Norris, Tenn.

Snowdon, P., J. Raison, H. Keith, P. Ritson, P. Grierson, M. Adams, K. Montagu, H. Bi, W. Burrows, and D. Eamus. 2002. Protocol for sampling tree and stand biomass. National carbon accounting system technical report no. 31. Australian Greenhouse Office. Canberra.

Van Lear, D.H. and P.R. Kapeluck. 1995. Aboveand below-stump biomass and nutrient content of mature loblolly pine plantation. Can. J. For. Res. 25:361-367.

Wetzel, S., C. Demmers, and J.S. Greenwood. 1989. Seasonally fluctuating bark proteins are a potential form of nitrogen storage in three temperate hardwoods. Planta 178:275281

Zianis, D. and N. Mencuccini. 2004. On simplifying allometric analysis of forest biomass. For Ecol. Manage. 187:311-332. 